\title{
CRISE DOS PODERES DA REPÚBLICA NO ESTADO DEMOCRÁTICO DE DIREITO: UM NOVO LEVIATÃ
}

\section{CRISIS OF THE POWERS OF THE REPUBLIC IN THE DEMOCRATIC STATE OF LAW: A NEW LEVIATAN}

Flávio Luís Oliveira

\begin{abstract}
Doutor e Mestre em Direito pela Universidade Federal do Paraná - UFPR. Professor Permanente dos Cursos de Mestrado e Doutorado em Direito do Centro Universitário de Bauru/SP, mantido pela Instituição Toledo de Ensino - ITE. E-mail: flavioluis@terra.com.br
\end{abstract}

Ricardo Augusto Bragiola

Mestre e doutorando em Sistema Constitucional de Garantia de Direitos pelo Centro Universitário de Bauru/SP, mantido pela Instituição Toledo de Ensino - ITE. Especialista em Direito Empresarial pela Fundação Getúlio Vargas (GVLaw) de Ribeirão Preto/SP. Advogado e professor universitário. E-mail: ricardobragiola@gmail.com

Recebido em: 14/08/2017

Aprovado em: 15/11/2017

Doi: $10.5585 /$ rdb.v18i7.778

RESUMO: O presente trabalho abordará a problemática e conflituosa relação existente entre o novo constitucionalismo no Brasil e a nova processualística do atual Código de Processo Civil, pouco democráticos quando vistos com relação aos outros Poderes constituídos. Em particular, o presente trabalho enfocará a administração da justiça pelo Poder Judiciário, o qual submete a democracia brasileira em aceitar o império do Poder Judiciário. Somente existe Estado Democrático de Direito, se se distingue claramente entre aquilo que o legislador impôs como norma e aquilo que um intérprete apresenta como razões para uma determinada interpretação por meio de uma fidelidade à lei.

Palavras-chave: Constitucionalismo Brasileiro; Pode Judiciário Autoritário; Novo Código de Processo Civil; Estado Democrático de Direito.

\begin{abstract}
This paper will deal with the problematic and conflictual relationship between the new constitutionalism in Brazil and the new proceduralism of the current Code of Civil Procedure, which are not democratic when viewed in relation to other constituted Powers. In particular, the present work will focus on the administration of justice by the Judiciary, which submits Brazilian democracy to accept the empire of the Judiciary. There is only a democratic state of law if one clearly distinguishes between what the legislator has imposed as a norm and what an interpreter presents as reasons for a certain interpretation by means of a fidelity to the law.

Keywords: Brazilian Constitutionalism; Can Authoritarian Judiciary; New Code of Civil Procedure; Democratic state.
\end{abstract}


SUMÁRIO: Introdução; 1. A nova processualística Civil Brasileira e o ativismo judicial: o Poder Judiciário como um novo Leviatã; 2. Por um constitucionalismo democrático e humanista: a democracia através dos direitos e da harmonia dos poderes constituídos; Conclusão; Referências bibliográficas.

\section{INTRODUÇÃO}

O presente trabalho abordará a problemática e conflituosa relação existente entre o constitucionalismo, o ativismo judicial no Brasil e a nova processualística do atual Código de Processo Civil, pouco democráticos para com relação aos outros Poderes constituídos na Constituição Federal de 1988. Em particular, o presente trabalho enfocará a administração da justiça pelo Poder Judiciário, o qual submete a democracia brasileira em aceitar um novo império, agora do Poder Judiciário, o qual destoa em uma juristocracia ${ }^{1}$, como uma farsa e embuste da "justiça", pois o Poder Judiciário não tem o papel constitucional de governar o país, mas sim ser mais um (dentre outros) dos Poderes constituídos.

Neste contexto, questiona-se: o juiz resolve(rá) (todas as) crises do cumprimento da lei ou as criam, sem, contudo, imparcialidade, racionalidade e limite institucional? A dúvida de Paulo Ferreira da Cunha² é atualíssima para com o cenário brasileiro: "Será o Estado, hoje, uma pessoa de bem, capaz de garantir a isenção e independência que garantam o não exercício da vingança pelo monopólio da coação?" Infelizmente, no Brasil, eis que as respostas para as indagações acima estão contidas na problemática da juristocracia, ou melhor, na supremocracia ${ }^{3}$.

Por outro lado, os postulados constitucionais e a realidade social 'impõem' um Judiciário 'intervencionista' capaz de exigir a consecução de políticas sociais eficientes, vinculado às diretrizes constitucionais. Embora a conceituação clássica da divisão dos poderes tenha exposto o Judiciário à resoluta função de decidibilidade dos conflitos segundo os métodos de aplicação do Direito dogmatizado e pragmático, o que o relegou a uma posição passiva prostrada à conjuntura normativa, a desneutralização em busca da efetividade dos direitos fundamentais sociais importa, além dessa relevante conquista, na conscientização do juiz no sentido de avançar sobre um conceito de justiça mais amplo que a mera regência jurisdicional pela batuta legalista, afastando-se da 'legolatria', evitando-se, por fim, ser tido como a mera 'boca da lei'.

No entanto, é sensitivo que o ordenamento jurídico, por ter adotado uma feição que contemplou os interesses capitalistas, desenhou o Poder Judiciário dentro de um contexto que privilegiou os interesses patrimoniais como se verificou no formato dos revogados Código Civil de 1916, bem como no Código de Processo Civil de 1973.

Atualmente, o ordenamento jurídico, sob os influxos dos anseios neoliberais, deixa transparecer nitidamente sua preocupação com a distribuição veloz da justiça. Há uma inequívoca neurose e predisposição em entregar ao Poder Judiciário mecanismos que possibilitem a obtenção de soluções rápidas para os litígios que lhes são trazidos. A racionalidade jurídica e a

\footnotetext{
1 Ran Hirschl define esse processo como "juristocracia" (juristocracy) a progressiva transferência de poderes decisórios das instituições representativas para o Judiciário. Tal fenômeno é acompanhado e alimentado por uma mudança na ideologia jurídica, consistente em uma crítica crescente realizada pelas principais elites políticas, jurídicas e econômicas à premissa majoritária que define a democracia em sua dimensão popular. Cf. HIRSCHL, R. Towards juristocracy: the origins and consequences of the new constitutionalism. Cambridge, Massachusetts: Harvard University Press, 2004 apud GARRIDO, Alexandre (et. al.). A função legislativa do Supremo Tribunal Federal e os Partidos Políticos. Revista Jurídica da Faculdade Nacional de Direito da UFRJ. V. 1, n. 3 (Edição Especial), dez. 2008, Rio de Janeiro, Faculdade Nacional de Direito, 2008, p. 52.

${ }^{2}$ CUNHA, Paulo Ferreira da. Direito constitucional e fundamentos do direito - Diálogos interdisciplinares. Rio de Janeiro: Renovar, 2008, p. 81.

${ }^{3}$ VIEIRA, O. V. Supremocracia: vícios e virtudes republicanas. Valor Econômico. 06 de novembro de 2007.
} Revista de Direito Brasileira | São Paulo, SP | v. 18 | n. 7 | p. 114 - 133 |Set./Dez. 2017 
preocupação com os anseios de justiça, desse modo, cedem lugar à celeridade. É intuitivo que o Poder Judiciário está sendo alimentado por mecanismos que o tornem rápido, sem que, no entanto, seja observado que o preço dessa celeridade é a frustração da justiça, o sepultamento dos direitos fundamentais sociais e a violação da democracia com a desarmonia entre os Poderes constituídos.

Há, nesse passo, um contragolpe na desneutralização do próprio Poder Judiciário na medida em que a velocidade torna a jurisdição mecânica (neutra), como se a distribuição da justiça dependesse do acionamento da tecla 'copiar/colar'. Dentre outros, a redução dos precedentes às súmulas, a sua indevida equiparação e a consequente aplicação distorcida do stare decisis é um reflexo desta patologia.

Abandonar essa tendência direcionada à velocidade parece constituir desafio fundamental para a efetiva desneutralização do Poder Judiciário. A esperada 'desneutralização', como dito, evidenciada pela possibilidade da construção da ação ou do procedimento, conforme as necessidades substanciais carentes de tutela e as particularidades do caso concreto, eis que exige um Juiz além de preparado, comprometido com os postulados constitucionais, pois do contrário, resta frustrada na medida em que o ideal absolutista da celeridade impõe decisões calcadas em enunciados normativos que não necessariamente representam a decisão justa ou o precedente adequado e, pior, muito pior, nem mesmo representa a aplicação da lei elaborada pelo Poder Legislativo, mas tão somente àquelas editadas pelo Poder Judiciário, via súmula, precedentes, etc. A baixa carga hermenêutica desaparece; não há mais interpretação, reflexão, argumentação. Há, sim, subsunção à súmula. Ora por comodismo, ora por acúmulo de trabalho, o magistrado não passa de mera 'boca da súmula'. A 'legolatria' dá espaço à 'sumulatria'.

Frise-se, não obstante as reformas processuais, o Poder Judiciário na instância inicial e ordinária continua neutro, para não dizer 'neutralizado'. Antes, a mera aplicação da lei, fruto da atividade, observadas as regras do processo legislativo constitucional, do Poder Legislativo e Executivo. Agora, a mera aplicação da súmula, fruto do Poder Judiciário. Antes das reformas processuais civis iniciadas no final do século passado, como dito, o legislador construía procedimentos e indicava a técnica processual a ser aplicada à determinada situação de direito material, invariavelmente de cunho patrimonial. Agora, a cúpula do Poder Judiciário (11 ministros do Supremo Tribunal Federal e 33 ministros do Superior Tribunal de Justiça), através das súmulas ditam as técnicas e a solução abstrata para os casos concretos que julgam relevantes.

Por óbvio que, se o legislador não se posiciona na defesa dos direitos fundamentais, cabe ao magistrado adotar uma postura prospectiva, diante da sua responsabilidade finalística, o que, por evidência, não se confunde com a faculdade de adotar esse padrão dito 'desneutralizado'. Vale dizer, assim como as mais variadas técnicas dispostas no sistema processual não podem constituir um 'fim em si mesmo', o sistema processual não pode estar comprometido apenas e tão somente com a celeridade, embora o 'discurso' seja da segurança jurídica, previsibilidade e igualdade nas decisões.

Tais postulados principiológicos somente seriam materializados se o sistema brasileiro fosse realmente calcado na comunhão entre o precedentalismo, conforme suas raízes históricas, e o procedimentalismo otimizado. A nossa realidade não é essa. Ainda que não se possa negar a existência das súmulas diante da previsão constitucional, o processo de construção, ao que tudo indica, ocorre às avessas: ao invés de o precedente informar a edição da súmula, que deveria ser tida como 'ponto de partida' na pesquisa hermenêutica inerente à formatação da decisão fundante; a conveniência na edição de eventual súmula exige a busca de precedentes que aparentemente a justifique, o que explica, não raras vezes, o fato de a súmula não contemplar todos os motivos determinantes do precedente, construídos sob o pálio do contraditório e da ampla defesa, ou, o mais grave, dele se desgarrar por completo.

Nessa linha, no processo de construção de igualdade e de consolidação de cidadania, revela-se essencial a reflexão acerca das estruturas e técnicas necessárias a ensejar a 
operacionalização de um modelo jurisdicional que viabilize o efetivo acesso aos direitos abstratamente proclamados pela Constituição Federal. Para tanto, revela-se fundamental a 'abertura' em relação ao processo hermenêutico e, por consequência, aos meios e técnicas processuais a ensejar a efetividade dos pronunciamentos judiciais. Portanto, tal visão em relação ao sistema jurídico-processual contribuirá para a consagração da democracia na perspectiva material, não meramente representativa de uma maioria legislativa eventual, tampouco, da restrita cúpula do Poder Judiciário.

Desta feita, da análise e enfrentamento dessas questões poderá resultar certa fratura ideológica que pode ter repercussões organizativas, sem perder de vista a lealdade aos ideais sociais e políticos da sociedade brasileira. Tal aspecto não deve ser visto como patológico, mas sim fisiológico. De fato, as eventuais fraturas e conflitos decorrentes deste embate, além de serem inerentes à democracia, constituirão a verdadeira alavanca do processo de consolidação da justiça brasileira na perspectiva substancialista, portanto, de concretização dos direitos fundamentais sociais.

O Estado Democrático de Direito proclama e defende a liberdade dos cidadãos e os limites dos detentores do Poder. Os atos do Poder Judiciário brasileiro provocam alarme e espanto e deixam a Constituição e a harmonia dos Poderes um tanto quanto abalados, fragilizando tanto a segurança jurídica quanto os direitos fundamentais. A Constituição Federal de 1988, no título I, dos princípios fundamentais, em seu artigo $2^{\circ}$, diz que "são Poderes da União, independentes e harmônicos entre si, o Legislativo, o Executivo e o Judiciário”. Entretanto, não são raras as vezes que os Poderes (em especial o Poder Judiciário) atuam com muita mais independência do que aquela dada pela Constituição Federal, o que resulta em uma verdadeira crise do Estado Democrático de Direito.

Neste ponto, muito embora venha ocorrer uma crise institucional, a Constituição de 1988 tem um espírito garantista de direitos em sua matéria e forma, ou seja, independentemente da crise estatal (entre os Poderes constituídos) os direitos fundamentais devem prevalecer ${ }^{4}$.

Neste passo, toda vez que se atropela o que está previsto em uma norma constitucional, eis que se colocam em segundo plano as liberdades constitucionais e até mesmo o próprio Estado Democrático de Direito. Ninguém está acima da lei ou deve atuar à margem da lei, pois fora da lei não há salvação e muito menos há salvação na "bondade" do julgador. A correção de rumos deve ser pelas Instituições constituídas e de acordo com a Constituição. Jamais ao sabor das paixões, pois somente assim haverá uma aproximação dos fins constitucionais aos resultados fáticos e jurídicos, de modo que o direito constitucional e a justiça social não fiquem esquecidos ou previstos tão somente em uma folha de papel ou menos que isto, mas sim que haja um cumprimento da normatização dirigente da Constituição Brasileira dentro da referida problemática, tendo em vista que há uma real ameaça de ruptura constitucional ou de ruptura social.

Aqui vale lembrar que o exercício da função de controle da atuação dos demais Poderes, a proteção de grupos vulneráveis e dos direitos fundamentais, dentro dos limites constitucionais, eis que não é uma mera faculdade apresentada ao Judiciário, mas sua razão de "ser" e, enquanto detentor do poder de controlar outros Poderes ou dar a última palavra na maioria dos casos, eis que também deve ser controlado no sistema de freios e contrapesos de si mesmo, pelo que não há poderes soberanos.

\footnotetext{
4 “A Constituição é o Estatuto do Governo, o qual é uma Instituição, com regulamento, lei interna, estatuto, onde o uso do Poder tem limites, constitui abuso intolerável, porque é ofensa à liberdade própria do ser humano. É preciso lembrar que as Constituições resultaram de uma longa evolução histórica, de uma longa luta do povo contra o absolutismo nos monarcas. As Constituições são o coroamento das insurreições dos governados contra a prepotência e o arbítrio dos governantes. [...] O Poder Público arbitrário foi substituído pelo Poder Público limitado pelos chamados Direitos do Homem ou Direitos Humanos." TELLES JÚNIOR, Goffredo. A Constituição, a Assembleia Constituinte e o Congresso Nacional. São Paulo: Saraiva, 1986, p. 4 e seguintes.
}

Revista de Direito Brasileira | São Paulo, SP | v. 18 | n. 7 | p. 114 - 133 |Set./Dez. 2017 
Portanto, para se combater Poder(es) abusivo(s), faz-se necessário uma cidadania esclarecida que requeira sobremaneira o acesso à justiça plena no devido processo legal com vistas a proteção dos direitos fundamentais.

\section{A NOVA PROCESSUALISTICA CIVIL BRASILEIRA E O ATIVISMO JUDICIAL: O PODER JUDICIÁRIO COMO UM NOVO LEVIATÃ}

\section{O Novo Código de Processo Civil não se põe à altura da missão do Estado} Constitucional Democrático e da Constituição Federal de 1988, pelo que tal situação acrítica, de inércia, de atraso e de indiferença para com os jurisdicionados, deve-se, então, às algumas falácias ${ }^{5}$ que são repetidas desde longa data, a saber: i) a que tudo é justificável para reduzir a

${ }^{5}$ José Carlos Barbosa Moreira, na $8^{a}$ série de sua coleção intitulada "Temas de Direito Processual", citou alguns mitos sobre o futuro da justiça, o qual foi objeto de uma conferência que pronunciara em 05 de abril de 2000, no Rio de Janeiro. Referidos mitos, segundo o jurista, eram fenômenos presentes naquela época e que ele não tinha expectativa de revelações sensacionais sobre o porvir da Justiça e nem tinha a pretensão de cultivar a futurologia. Referido jurista estava equivocado, infelizmente, pois são atualíssimos seus ensinamentos e pior, muito pior, não foram observados (ou foram observados, mas com vistas grossas) para que fossem objeto de discussão frente as necessárias mudanças do direito processual civil, sobretudo para afastar cogitações desarrazoadas. No primeiro mito, o jurista já fala sobre a rapidez acima de tudo (ou: quando mais depressa, melhor), relativamente a duração dos processos, não por acaso vista como excessiva por tantos observadores, pelo que o jurista subdividiu referido mito em quatro submitos, sendo: $1^{\circ}$ - é a crença, bastante difundida, de que se cuida de fenômeno exclusivamente brasileiro, mas que o jurista tratou de citar inúmeros outros exemplos de todas as partes do mundo que na verdade se tratava de um problema global; $2^{\circ}$ - é a ideia de que todos os jurisdicionados clamam, em quaisquer circunstâncias, pela solução rápida dos litígios e, no caso, trata-se de uma ideia ingênua; $3^{\circ}$ - a crença de que são os defeitos da legislação processual a maior responsabilidade pela duração excessiva dos pleitos, mas o jurista cita inúmeros outros fatores, entre os quais: a escassez de órgãos judiciais e o aumento populacional; insuficiente preparo de muitos juízes, bem como o do pessoal de apoio; divisão irracional do território em comarca, em algumas das quais se torna insuportável a carga de trabalho, enquanto noutras, pouco movimentadas; a defeituosa organização do trabalho e a insuficiente utilização da moderna tecnologia, que concorrem para reter em baixo nível a produtividade; e câmaras de um mesmo tribunal, sob idênticos regimentos e condições de trabalho, pelos diversos órgãos fracionários, julgam em tempos diferentes, sendo umas mais morosas e outras mais céleres. Não convém esquecer, por outro lado, que há uma demora fisiológica, consequente à necessidade de salvaguardar na atividade judicial certos interesses e valores de que uma sociedade democrática não ousaria prescindir. Insiste-se na escrupulosa observância de tais ou quais garantias das partes - ao menos, diga-se de passagem, quando se trata de pessoas simpáticas à opinião pública (ou melhor, à opinião publicada, que com aquela ingenuidade somos levados a confundir). Ora, um processo de empenho garantístico é por força um processo menos célere. Dois proveitos não cabem num saco, reza a sabedoria popular. É pretensão desmedida querer desfrutar ao mesmo tempo o melhor de dois mundos. Nada mais sumário e rápido que o linchamento do réu; mas tolerar semelhante prática hoje em dia parece inconcebível, por maior frequência que se observe ainda em tentativas, às vezes bem-sucedidas, de empregá-la - senão no sentido físico, seguramente no moral - para com certos réus que incorrem, por isto ou por aquilo, nas iras especiais da imprensa e de outros meios de comunicação social. Prosseguindo, no submito $4^{\circ}$, o jurista cita como o mais perigoso, consistente em hiperdimensionar a malignidade da lentidão e sobrepô-la, sem ressalvas nem matizes, a todos os demais problemas da Justiça. Para muita gente, na matéria, a rapidez constitui o valor por excelência, quiçá o único. E o jurista continua: Seria fácil invocar aqui um rol de citações de autores famosos, apostados em estigmatizar a morosidade processual. Não deixam de ter razão, sem que isso implique - nem mesmo, quer crer o jurista, no pensamento desses próprios autores - hierarquização rígida que não reconheça como imprescindível, aqui e ali, ceder o passo a outros valores. Se uma justiça lenta demais é de certo uma Justiça má, daí não se segue que uma Justiça rápida seja necessariamente uma Justiça boa. Alerta o jurista que todos devemos querer é que a prestação jurisdicional venha a ser melhor do que é. Se para torná-la melhor é preciso acelerá-la, muito bem: não, contudo, a qualquer preço. No segundo mito, o referido jurista denomina como "fórmula mágica" (ou "abracadabra"), no sentido de afirmar que não existe uma única fórmula, seja ela a arbitragem, a oralidade do processo, a redução de prazos e de recursos, universalização de Juizados Especiais, outros meios alternativos de composição dos litígios, mas, ao final, o jurista fala sobre a necessidade de combinar estratégias e táticas, pondo de lado o receio de parecermos incoerentes se, para enfermidades de diferentes diagnósticos, experimentarmos remédios também diferenciados. O simplismo das palavras de ordem, já indesejável na política, revela-se aqui funesto. O terceiro mito refere-se à supervalorização de modelos estrangeiros (ou "a galinha da vizinha é sempre mais gorda que a minha"). Neste ponto, além de indicar a necessidade de examinar a fundo o modo como na prática funciona o instituto de que se cogita no país de origem Revista de Direito Brasileira | São Paulo, SP | v. 18 | n. 7 | p. 114 - 133 | Set./Dez. 2017 
quantidade de processos, diante do acúmulo de recursos nos tribunais e do aumento da judicialização da vida em sociedade, os quais contribuem para que a garantia do devido processo legal não tenha a necessária atenção que exigiria quanto a sua essencialidade para solução qualitativa das lides; ii) a commonlização do direito processual brasileiro, com apanhados didáticos, inexatos e quase sempre deformados, incomensurável entre sistemas processuais e do próprio Direito contemporâneo; iii) a jurisprudencialização do Direito, como uma transplantação de categorias e raciocínios do Direito sem se darem conta os transplantadores da diferença de natureza entre os ramos do Direito, e de conceitos e direitos fundamentais, dentre outros, de modo que sofre influxos de predadores exógenos (mídia, religião, política, moral e economia) e endógenos (pan-principiologismo, relativização da coisa julgada, commonlização e discricionariedades); iv) a discricionariedade nas decisões judiciais de um juiz que se mostra o condutor do processo e o destinatário final da(s) prova(s) - em que compete a ele decidir acerca da conveniência (ou não, na maioria das vezes) da instrução processual; e (v) que o processo passa a ser apenas e tão somente uma segunda ordem não suscetível de tratamento filosófico, racional, nem das preocupações de alta dogmática jurídica.

Pois bem. O Código de Processo Civil de 2015 carrega consigo inúmeras deficiências, em especial a falta de limites do Poder Judiciário em dominar os contornos da lei, bem como quando se verifica que não há preocupação com a qualitativa distribuição de justiça ao povo, mas tão somente com a quantitativa resolução das lides acumuladas nas prateleiras empoeiradas dos tribunais, resultando, por conseguinte, na técnica pela técnica, ou seja, o que importa é a quantidade de "extinção" dos processos ${ }^{6}$ e não a qualidade na condução dos mesmos para um processo $^{7}$ justo, no sentido de concretizar a distribuição de justiça e proteção dos direitos fundamentais via devido processo legal constitucionalmente garantido a todos.

com análise direta às fontes, o conhecimento dos textos originais, a consulta das jurisprudências e da doutrina alienígena, a fim de evitar erros de perspectiva, o jurista ressalta também a necessidade de verificar a compatibilidade com o tecido do ordenamento no qual se quer enxerta-la. Aqui se faz mister passar cuidadosa revista não apenas nos dados normativos, senão também nos costumes judiciários, a formação do profissional e a mentalidade das classes mais diretamente envolvidas - juízes e advogados, cuja colaboração franca será imprescindível ao êxito da operação. E o jurista questiona: Modos novos de agir não se assimilam de um dia para outro. Que advogados brasileiros, por exemplo, estariam habilitados de imediato a proceder, como seus colegas norte-americanos, à cross-examination de testemunhas? E que juízes nacionais, com ou sem martelo, seriam capazes de presidir ao ato com a olímpica impassibilidade em que costumam manter-se os trial judges dos Estados Unidos? No caso de nosso país, o máximo de cuidado há de ser posto justamente na abertura das portas jurídicas aos produtos vindos dos Estados Unidos, dada a notória diferença estrutural dos dois sistemas - o brasileiro, de linhagem europeia continental, com o predomínio das fontes escritas, e o norte-americano, muito mais afeiçoado à formação jurisprudencial do direito. No caso, o jurista declara, por exemplo, acerca da atribuição de ef̧icácia vinculativa a precedentes judiciais, que a julga conatural a este último sistema, enquanto parece duvidoso, para dizer o menos, que se harmonize com aquele. Por fim, no quarto mito, o jurista José Carlos Barbosa Moreira fala sobre a onipotência da norma (ou: "vale o escrito"). As reformas legislativas ou não, tanto uma como outra deixariam as coisas exatamente onde estavam. A norma, vale sublinhar, nem é impotente, nem onipotente. MOREIRA, José Carlos Barbosa. Temas de direito processual: oitava série. São Paulo: Saraiva, 2004, p. 1 e seguintes.

${ }^{6}$ E não é de hoje que isso ocorre. Para tanto, basta verificarmos que, não raras vezes, analistas destacam que o Supremo Tribunal Federal dedica a maior parte de suas decisões a questões de direito processual e não a questões substantivas. FALCÃO, Joaquim de Arruda. O Judiciário e o acesso à justiça. In: SADEK, Maria Tereza (Org.). $O$ Judiciário em debate. São Paulo: Idesp/Sumaré, 1995, p. 24.

7 O processo, neste artigo, é entendido como relação jurídica de caráter público, com a peculiaridade de se desenvolver numa extensão temporal com a concorrência de um representante do Estado e dos sujeitos interessados na decisão que afinal deverá obter como resultado. Nos ensinamentos de Willis Santigo Guerra Filho, com base em Niklas Luhmann, há uma formula também relativa a legitimidade obtida através do procedimento, com uma dimensão filosófica e política do fenômeno, numa investigação de caráter sociológico tendo-o como objeto. E continua em seus ensinamentos referido jurista que: $\mathrm{O}$ movimento histórico de positivação do direito, desencadeado pela falência da autoridade baseada no divino, implica a formação de um aparato burocrático cada vez maior para implementação da ordem jurídica. Tanto a legislação, como a administração da res publica e de justiça, necessitam de formas procedimentais dentro das quais possam atuar atendendo aos novos padrões legitimadores do direito, baseados na racionalidade e no respeito ao sujeito, portador dessa faculdade. O processo aparece, então, como Revista de Direito Brasileira | São Paulo, SP | v. 18 | n. 7 | p. 114 - 133 |Set./Dez. 2017 
Neste sentido, a processualística proposta pelo Código de Processo Civil de 2015 visa o apressamento do processo para um término quase que antes da propositura da ação, como se o processo já fosse fadado a ser um "natimorto", sem, contudo, se preocupar com o devido processo legal e o esgotamento do acesso dos jurisdicionados para com todas as instâncias superiores $^{8}$. O resultado desta perigosa equação injusta é mais uma violação da dignidade da pessoa humana em ter o direito de acesso aos tribunais como uma garantia constitucional, enquanto ferramenta para a realização do direito material dentro de um processo justo, com ampla possibilidade de ação, de defesa, do contraditório. Atualmente, o que é visto, infelizmente, é uma mera reaplicação do Direito anteriormente utilizado em casos ditos como semelhantes, abreviando a participação do "ser" em juízo, sem se preocupar com os malefícios que isso trará para com o jurisdicionado e também para a própria ciência do Direito.

E nesta esteira, o devido processo legal já deve(ria) ser concretizado desde 1988, com a Constituição Federal, quando esta já prevê explicitamente os caminhos a serem seguidos pela processualística brasileira, sobretudo com a constitucionalização dos direitos e garantias individuais processuais, como uma conquista histórica - tal como todas as que foram alcançadas na eterna luta entre a Liberdade e o Poder -, que logrou adquirir substância e se converter em critério de verdade e racionalidade, obviamente ideológico, para o reconhecimento da existência da Constituição Federal e do próprio Estado Democrático de Direito, ao qual essas normas fundamentais deram configuração jurídica ao próprio Estado para adjetiva-lo como então Estado Constitucional Democrático. Como ressalta Flávio Luís de Oliveira9

No âmbito do direito processual constitucional, a tutela constitucional do processo (assentada em dois pilares estruturais: o acesso à justiça e o devido processo legal) tem por fim assegurar a conformação dos institutos processuais aos valores constitucionais. Assim, a tutela estatal deve realizar os direitos dos cidadãos e o princípio do acesso à justiça, insculpido no artigo $5^{\circ}$, incisos XXXV e LXXVIII, da Constituição Federal, constitui a principal garantia da satisfação destes direitos visando à realização dos fins do Estado. Logo, essa realidade normativa impõe a construção de procedimentos adequados às peculiaridades do direito material, bem como, a materialização de ações fáticas no sentido de se observar o fundamento da República, qual seja, a dignidade humana, nos exatos termos do artigo $1^{\circ}$, inciso III, da Constituição Federal. Nesta linha, no âmbito da atuação do Poder jurisdicional, a consagração deste fundamento enseja a releitura de vários conceitos tidos como estanques a fim de

resposta à exigência de racionalidade, que caracteriza o direito moderno. (...). Diante da complexidade do mundo quando (pós)moderno, as soluções melhores só aparecem quando se procura colocar as opiniões divergentes em comunicação, partindo de um consenso em torno da possibilidade de se chegar a um entendimento mútuo. Para isso, contudo, não se pode já partir de ideias preconcebidas, que se devem impor aos outros. GUERRA FILHO, Willis Santiago. Teoria processual da constituição. São Paulo: Celso Bastos Editor - Instituto Brasileiro de Direito Constitucional, 2000, p. 27 e seguintes.

${ }^{8}$ Aqui equivale a garantia do duplo grau de jurisdição, relativo ao direito subjetivo da parte em ver a sua pretensão de ser julgada pelo órgão colegiado, depois de submetida à apreciação do juiz singular. Está fundado na convicção generalizada de que um processo que foi reexaminado é melhor decidido. É a decisão colegiada que, em tese, dá uma satisfação ao inconformismo do vencido e evita autoritarismos, já que sobre as decisões não haveria controle algum. $\mathrm{Na}$ Constituição Federal, consta no artigo $5^{\circ}$, LV, que: aos litigantes, sem processo judicial ou administrativo, e aos acusados em geral são assegurados o contraditório e a ampla defesa, com os meios e recursos a ela inerentes. In: PARIZ, Ângelo Aurélio Gonçalves. O princípio do devido processo legal: direito fundamental do cidadão. Coimbra: Almedina, 2009, p. 245 e seguintes.

9 OLIVEIRA, Flávio Luís de. Tutela jurisdicional e concretização de direitos. In: Revista do Direito Privado (Londrina, Estado do Paraná), v. 03, p. 01-12, $2010 . \quad$ Disponível em: http://www.uel.br/revistas/direitoprivado/artigos/Flavio_Luis_Oliveira_Tutela_jurisdicional_concretiza\%C3\%A7\%C 3\%A3o_direitos.pdf. Acesso em 03 de novembro de 2016.

Revista de Direito Brasileira | São Paulo, SP | v. 18 | n. 7 | p. 114 - 133 | Set./Dez. 2017 
ensejar a inclusão social com base nos valores do Estado Democrático de Direito.

E, ainda, como se não bastasse, eis que o Código de Processo Civil de 2015 não se apresenta como ferramenta democrática à contenção do poder e do arbítrio - do próprio Poder Judiciário. O Estado, ao ser criado pela Constituição Federal, tem sua atuação (de)limitada dentro de uma ordem jurídica constitucional justa estabelecida e que deve ser cumprida, sob pena de morte do próprio constitucionalismo substancialista e, de outro lado, o nascimento da constitucionalização simbólica.

Como disposto no inciso LIV do artigo $5^{\circ}$ da Constituição Federal de 1988: "ninguém será privada da liberdade ou de seus bens sem o devido processo legal". Referido dispositivo constitucional protege amplamente a liberdade, a igualdade e a propriedade, mormente pela repercussão do patrimônio na vida pessoal e familiar e, extensivamente, somente com o devido processo legal garante-se ao cidadão uma atuação imparcial do Poder, protegendo a sua liberdade e seus bens, sendo cláusula constitucional frente aos Poderes Executivo, Legislativo e Judiciário.

A destituição do domínio de determinado bem, por isso mesmo, é medida de extrema gravidade nas constituições democráticas, as quais impõe aplicação de garantias próprias para legitimar tal situação, tal como o devido processo legal, o qual buscará a proibição de confisco, a exigência de cautelas na desapropriação, enfim, a proteção dos direitos fundamentais, as quais serão verificadas justamente em um processo justo.

Extrai-se do texto constitucional uma série de direitos fundamentais com tratamento autônomo e que impedem que a garantia do devido processo legal admita inferências do próprio Estado, pelo que são fórmulas protetivas que se identificam para a própria existência do Estado de Direito, tendo em vista a realização desse ideal do justo através de uma norma que deve adequar e conformar-se constitucionalmente para com o proceder dos protagonistas estatais e, ao final, legitimá-los à continuar exercer referido proceder. Assim, o próprio Estado de Direito deve proporcionar não só o devido processo legal no sentido processual e adjetivo, mas também no sentido substantivo para concretizar também a ideia de constitucionalismo substancialista ${ }^{10}$.

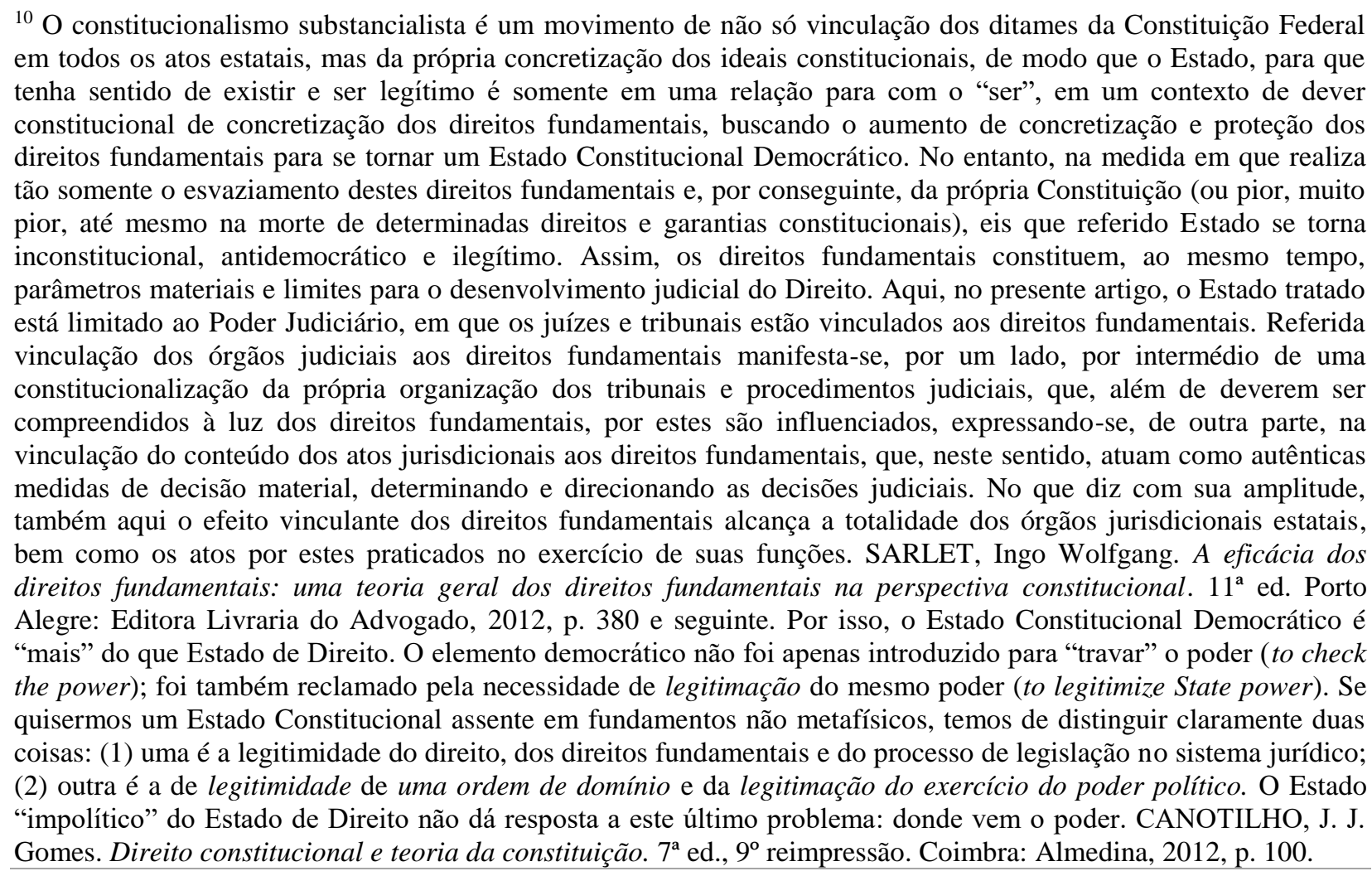
Revista de Direito Brasileira | São Paulo, SP | v. 18 | n. 7 | p. 114 - 133 |Set./Dez. 2017 
Com efeito, apesar da expressão do “devido processo legal” ter sido utilizada, pela doutrina e jurisprudência, com duas conotações diferentes e independentes ${ }^{11}$, eis que no presente artigo este termo é tratado enquanto uma garantia constitucional para construção da legitimidade material do próprio Poder Judiciário na aplicação da justiça frente ao caso concreto, de modo que afaste o apressamento de toda e qualquer decisão judicial tendente a dar uma resposta pronta antes mesmo da pergunta, o que nos remete então para discutir sobre o devido processo legal procedimental que, apesar de parecer redundante, é indicativo de exigência do respeito a um conjunto de garantias processuais mínimas para se chegar em um processo racional, adequado e justo. Dois exemplos, dentre vários, de que o Código de Processo Civil busca a técnica pela técnica, eis que estão refletidas propriamente: (i) tanto na redução de possibilidade de acesso aos tribunais superiores (ii) quanto no sistema precedentalista, os quais ambos vilipendiam a Constituição Federal, justamente ao não garantir um processo justo ou propriamente um devido processo legal procedimental democrático em si, entre as partes, e muito menos destas perante o Poder Judiciário.

Com o monopólio estatal da justiça, faz-se necessário que à medida que o Estado chama a si a função de julgar, a distribuição da justiça deve ser da forma mais científica de correção e racionalidade frente a um arcaico absolutismo persistente e que até hoje nunca fora superado, de modo que fique no passado a justiça dos (tribunais dos) reis para uma justiça dos tribunais ${ }^{12}$ para concretizar um nunca vivenciado Estado Constitucional Democrático.

Como prenunciado, não obstante ainda não haver um amadurecimento quanto à visão sistêmica e o emprego adequado das técnicas pelos atores judiciais das instâncias ordinárias, a cúpula do Poder Judiciário, ou seja, os membros do Supremo Tribunal Federal e do Superior Tribunal de Justiça não se contentam mais em compartilhar com o legislador o mencionado juízo de adequação ou conformação das técnicas ao caso concreto. Vale ressaltar que, "quando se pensa em 'caso concreto', e, assim, em particularidades insuscetíveis de previsão, há que se tomar em conta uma técnica legislativa que não defina, em abstrato, o instrumento processual que deve ser utilizado, mas sim aquilo que pode ser usado conforme as necessidades do caso concreto." 13

\footnotetext{
${ }^{11}$ A Constituição faz menção à locução devido processo legal (due process of law). A expressão é criticável no mínimo em duas frentes. Em primeiro lugar, porque remete ao contexto cultural do Estado de Direito (Rechtsstaat, État legal) em que o processo era concebido unicamente como um anteparo ao arbítrio estatal, ao passo que hoje o Estado Constitucional (Verfassungsstaat, État de Droit) tem por missão colaborar na realização da tutela efetiva dos direitos mediante a organização de um processo justo. Em segundo lugar, porque dá azo a que se procure, por conta da tradução estadunidense em que colhida, uma dimensão substancial à previsão (substantive due process of law), quando inexiste, para Luiz Guilherme Marinoni e Daniel Mitidiero, a necessidade de pensa-lo para além de sua dimensão processual no direito brasileiro. É preciso perceber que os deveres de proporcionalidade e de razoabilidade não decorrem de uma suposta dimensão substancial do devido processo, como parece ensinar parcela da doutrina (Carlos Roberto Siqueira e Castro e Nelson Nery Júnior). Os postulados da proporcionalidade decorrem dos princípios da liberdade e da igualdade - as posições jurídicas têm de ser exercidas de forma proporcional e razoável dentro do Estado Constitucional. De outro, importa ter presente que não é necessário recorrer ao conceito de substantive due process of law com o objetivo de reconhecer e proteger os direitos fundamentais implícitos, na medida em que nossa Constituição conta expressamente com um catálogo aberto de direitos fundamentais (art. 5. ${ }^{\circ}, \S$ $2 .^{\circ}$ ), o que desde logo permite a consecução desse mesmo fim: reconhecimento e proteção de direitos fundamentais implicitamente previstos e mesmo não previstos na Constituição (conceito material de direitos fundamentais). Eis as razões pelas quais prefere a doutrina se referir a direito ao processo justo (giusto processo, procès équitable, faires Verfahren, fair trial) - além de culturalmente consentânea ao Estado Constitucional, essa desde logo revela o cariz puramente processual de seu conteúdo. SARLET, Ingo Wolfgang; MARINONI, Luiz Guilherme; MITIDIERO, Daniel. Curso de direito constitucional. 4. ed. São Paulo: Saraiva, 2015, p. 731.

12 MIRANDA, Pontes de. Tratado da ação rescisória, das sentenças e de outras decisões. 5. ed. Rio de Janeiro: Forense, 1976, p. 5 e seguintes.

${ }^{13}$ MARINONI, Luiz Guilherme; ARENHART, Sérgio Cruz, MITIDIERO, Daniel. Curso de Processo Civil. Tutela dos direitos mediante procedimentos diferenciados. $2^{\mathrm{a}}$ edição. São Paulo: Revista dos Tribunais, 2016, p. 54.
}

Revista de Direito Brasileira | São Paulo, SP | v. 18| n. 7 | p. 114 - 133 | Set./Dez. 2017 
Em termos evolutivos, pode-se afirmar, de forma perfunctória, que a uniformidade procedimental cedeu lugar à construção de procedimentos diferenciados, sendo que agora o sistema processual civil contempla normas processuais de conteúdo aberto que permitem, dentro de certos limites, a construção da ação e do procedimento adequados às peculiaridades do direito material. Vale dizer, o foco de análise não fica mais restrito à abstração da ação; as reflexões dos juristas passam a contemplar, sobretudo, as mais variadas técnicas de concretização dos direitos.

Todavia, isso não basta! A cúpula do Poder Judiciário prefere definir a técnica e a solução em abstrato. Outrora utilizado como um sistema de dominação da elite econômica, atualmente o sistema processual civil brasileiro se traduz em uma forma de dominação da elite judiciária. De fato, antes da tomada de consciência quanto à necessidade de um amplo debate em relação à aplicação e incidência das regras processuais abertas às peculiaridades do caso concreto (artigo 139, IV e VI, do CPC), os atores das instâncias ordinárias deixaram de ser coadjuvantes e se tornaram meros figurantes no palco do judiciário, aliados a uma plateia acrítica, diante de um discurso que esconde ou oculta o verdadeiro roteiro da peça a cada dia encenada no Judiciário. Nesse processo de alienação, a venda de Têmis foi alocada nos olhos dos jurisdicionados e em boa parte daqueles que julgam nas instâncias ordinárias, transformados que foram em verdadeiras marionetes diante do enredo concebido e encenado pelos protagonistas do Poder Judiciário. Diante disso, a própria Têmis e os valores que a inspiram restaram limitados ou preteridos.

Nesse contexto, a atribuição, cada vez mais, de força impositiva às súmulas sob o argumento da previsibilidade, segurança jurídica e isonomia das decisões na perspectiva precedentalista revela uma perigosa forma discursiva de dominação pelo Poder Judiciário. $\mathrm{O}$ discurso diz respeito aos precedentes, mas, a realidade está pautada na aplicação desmedida e irrefletida das súmulas. Impõe-se poder vinculativo às súmulas sob a distorcida justificativa de adoção de um modelo precedentalista. Entretanto, súmulas e precedentes são institutos diametralmente distintos: os precedentes não se reduzem às súmulas, embora o legislador, de forma atécnica, os tenha equiparado para fins de fundamentação das decisões, de acordo com o artigo 489, parágrafo $1^{\circ}$, incisos V e VI, do Código de Processo Civil.

De fato, todas as complexidades de cunho jurídico, social, político e econômico contidas nas razões de decidir do precedente não são passíveis de serem reduzidas ao enunciado sumular. Ademais, não se desconhece que algumas súmulas não encontram respaldo nas circunstâncias fáticas e jurídicas dos respectivos precedentes que motivaram a sua criação, não obstante o disposto no artigo 926, parágrafo $2^{\circ}$, do Código de Processo Civil. Poder-se-ia sustentar que, na mesma medida em que a teoria tridimensional do direito, na perspectiva dos sistemas codificados, estaria assentada no fato, valor e norma; no âmbito precedentalista, devido a inegável existência das súmulas no sistema, revela-se necessária a correlação entre fato, precedentes e súmulas, no sentido que as súmulas somente devem assolar a situação fática quanto esta (situação fática) estiver respaldada nas razões de decidir (ratio decidendi) dos precedentes que ensejaram a criação daquela (súmula).

Como apontado, as súmulas deveriam ser tidas como 'ponto de partida' no âmbito da pesquisa hermenêutica para a melhor solução do caso concreto. Não é isso que acontece. As súmulas são aplicadas sem a devida análise de tal correlação com os precedentes o que gera, não raras vezes, interpretações equivocadas e a aplicação de precedentes às situações fáticas diversas daquela que gerou sua sedimentação, após exaustiva fundamentação, à luz do contraditório e da ampla defesa.

Sob esta perspectiva, há inegável baixa carga de legitimidade de tal pronunciamento judicial, pois, na medida em que a súmula é aplicada sem a devida análise e correlação com os motivos determinantes dos precedentes que lhe deram origem, toda a construção e dialética, sob o crivo do contraditório, desde as instâncias inferiores, sob o contexto histórico-social, restam prejudicadas. Não se desconhece a possibilidade de distinção e superação dos enunciados sumulares, inclusive, como critério de fundamentação e validade da decisão judicial o que 
poderia afastar a alegação de dominação pela elite judiciária ou a substituição da 'ditadura normativa' pela 'ditadura sumular'. Todavia, a edição da Lei 13.256/2016, que alterou o Código de Processo Civil em vigor ainda no período de vacatio legis, evidencia a política judiciária de 'fechamento' e a dificuldade para a superação das súmulas.

De fato, embora o debate, na ocasião, tenha girado em torno da nova redação do artigo 12 do Código de Processo Civil acerca do atendimento, preferencial, da ordem cronológica de conclusão dos feitos, as alterações perpetradas nos artigos 1.030 , parágrafos $1^{\circ} \mathrm{e} 2^{\circ}$, bem como no artigo 1.042, ambos do Código de Processo Civil, modificaram, sensivelmente, o sistema recursal. O discurso se pautou apenas e tão somente em relação à ordem cronológica da conclusão dos feitos, o que ocultou, ao que tudo indica de forma premeditada, a principal finalidade da alteração legislativa defendida pela Associação dos Magistrados do Brasil - AMB, ou seja, as alterações no sistema recursal como forma de manutenção, inclusive, dos enunciados sumulares, pois, tornou-se mais difícil a sua revisitação, sobretudo, para ensejar eventual superação do entendimento.

Vale dizer, caso a decisão que inadmitir recurso extraordinário ou recurso especial esteja fundada na aplicação de entendimento firmado em regime de repercussão geral ou em julgamento de recursos repetitivos, caberá apenas agravo interno, nos termos do artigo 1.021 do CPC, de acordo com o artigo 1030, parágrafo $2^{\circ}$, do mesmo diploma legal. Desta feita, não obstante o artigo 489, inciso VI, do CPC exigir, como critério de validade, a argumentação acerca da demonstração da distinção ou superação do entendimento em relação à precedente, súmula ou jurisprudência (equiparação contida no próprio dispositivo), o recurso cabível em caso de inadmissão do recurso extraordinário ou especial, diante da existência de entendimento firmado em regime de repercussão geral ou em julgamento de recursos repetitivos será o agravo interno dirigido ao órgão colegiado do tribunal recorrido o que, certamente, dificultará (para não dizer impedirá) a distinção ou superação do respectivo entendimento firmado.

Por outro lado, as alterações perpetradas no âmbito da Reclamação, especificamente no artigo 988, parágrafo $4^{\circ}$, do CPC, dizem respeito à aplicação indevida da tese jurídica e sua não aplicação aos casos que a ela correspondam. Note-se que não foi abordada a hipótese de superação do entendimento. Portanto, não há dúvida que as alterações do sistema recursal geraram maior dificuldade para a distinção e superação de eventual precedente ou súmula, equiparados que foram indevidamente. Ademais, a proposta de emenda constitucional (PEC 209/12), já aprovada em $1^{\circ}$ turno na Câmara dos Deputados, estabelece que, "no recurso especial, o recorrente deverá demonstrar a relevância das questões de direito federal infraconstitucional discutidas no caso, nos termos da lei, a fim de que o Tribunal examine a admissão do recurso, somente podendo recusá-lo pela manifestação de dois terços dos membros do órgão competente para o julgamento". Trata-se da chamada "PEC da Repercussão Geral no STJ."

Tal proposta, caso seja aprovada, alterará o artigo 105 da Constituição Federal de modo a limitar, ainda mais, a utilização do Recurso Especial e, consequentemente, a 'oxigenação' ou 'arejamento' dos entendimentos firmados no âmbito dos Tribunais Superiores o que acarretará a utilização desmedida das Súmulas, inclusive, como instrumento de dominação vertical (endógena), bem como horizontal (exógena), respectivamente em relação aos Juízes de 'piso' e os demais Poderes. (O que dizer dos jurisdicionados?)

Além disso, há um 'encastelamento' dos Tribunais Superiores que objetivam, em flagrante inconstitucionalidade, a redução de competências que lhe foram atribuídas pela Constituição Federal. Exemplo disso se materializa na Resolução 03/2016 do Superior Tribunal de Justiça que delegou aos tribunais de justiça dos estados a competência para a apreciação das reclamações interpostas em razão das decisões das turmas recursais dos juizados especiais.

Consoante se depreende da redação do artigo $1^{\circ}$ da aludida Resolução, a competência para julgamento de tais reclamações fora deslocada aos tribunais de justiça locais, sob o 
argumento de que há um fluxo volumoso de Reclamações no Superior Tribunal de Justiça envolvendo os Juizados Especiais.

Além do nítido objetivo de delegar competência em flagrante inconstitucionalidade, a aludida Súmula contraria o disposto no artigo 988 , parágrafo $1^{\circ}$, do atual Código de Processo Civil que estabelece que o julgamento da Reclamação compete ao órgão jurisdicional cuja competência se busca preservar ou cuja autoridade se pretenda garantir. ${ }^{14}$ Logo, trata-se de distribuição de competências entre os órgãos jurisdicionais que, por óbvio, por se tratar de matéria constitucional, não pode ser objeto de Resolução emanada do Superior Tribunal de Justiça.

Constata-se, assim, que além da indevida equiparação entre precedentes e súmulas e todos os aspectos daí decorrentes, bem como do 'fechamento' do sistema recursal, a 'dominação' perpassa pelo deslocamento de matérias originariamente de competência do Superior Tribunal de Justiça para a apreciação dos tribunais dos estados da federação, o que denota a 'política judiciária' de 'engessamento' que se instalou no sistema jurídico brasileiro, sobretudo, no sistema processual civil com graves reflexos na democracia.

Embora seja possível reconhecer que o procedimento inerente ao sistema processual civil, com as reformas iniciadas nos idos de 1990, em certa medida, embora limitada, democratizou-se em busca da 'desneutralização' do Poder Judiciário, tal avanço restou tolhido e emasculado em virtude da atual forma de 'neutralização'. Outrora, o Poder Legislativo alimentou um sistema patrimonializante das elites. Agora, o Poder Judiciário alimenta um sistema dominante da sua própria elite. Em ambas as situações, algo em comum: o Poder.

Ainda hoje é possível constatar que não foram encontradas respostas adequadas aos problemas gerados pelo Poder, muito menos uma solução legal e normativa capaz de erradicar o seu uso abusivo no Estado Democrático de Direito. Há, evidentemente, um alargamento espacial da democracia, porém, vem comprovando que, se é verdade que os totalitarismos não resolvem de maneira duradoura as questões sociais mais graves, não há evidências de que a prosperidade e a justiça social sejam promovidas pela democracia como uma consequência direta. Pobreza e liberdades políticas podem ser compatibilizadas pelo controle social fundado em aceitações culturais e na manipulação de informações. Ou mesmo no recurso à força legalmente exercida em momentos especiais de instabilidade ou até mesmo em outras formas de autoritarismo como uma "lamentável" necessidade.

Neste contexto, são precisas as palavras de Norberto Bobbio, ao dizer que "nada ameaça mais matar a democracia que o excesso de democracia"15 e é justamente aqui o ponto que é necessário chamar a atenção da sociedade para voltar os olhos para com o próprio Poder Judiciário, do qual, em um Estado Democrático de Direito, não possui qualquer limitação ${ }^{16}$.

\footnotetext{
${ }^{14}$ Esse aspecto foi muito bem apontado no procedimento de controle administrativo $\mathrm{n} .{ }^{\circ}$ 0002921-97.2016.2.00.0000 interposto perante o CNJ - Conselho Nacional de Justiça.

${ }^{15}$ BOBBIO, Norberto. O futuro da democracia - Uma defesa das regras do jogo. $4^{\mathrm{a}}$ ed. Rio de Janeiro: Paz e Terra, p. 27.

${ }^{16}$ Ivar Hartmann sintetiza alguns poderes ilimitados do Supremo Tribunal Federal, a saber: O "timing" das decisões do plenário é um elemento decisivo e pouco conhecido pela sociedade. O Supremo pode decidir uma liminar em 20 horas (ADI 4.698) ou em 18 anos (ADI 1.229). Não há qualquer regra sobre isso. Não há qualquer mecanismo de freio ou contrapeso. Atualmente, o tribunal pode escolher se irá decidir o pedido de afastamento de Eduardo Cunha na semana que vem ou no final do ano. [...] Dados do projeto Supremo em Números [http://www.fgv.br/supremoemnumeros/] mostram que, entre 2009 e 2013, 98\% das decisões de mérito e liminares foram individuais. Assim foram as decisões monocráticas de Gilmar Mendes e Teori Zavascki sobre a questão do foro competente para julgar Lula. Separadas por quatro dias e aparentemente conflitantes. Ambas garantindo que, por algum tempo, a posição pessoal do ministro se torne a posição oficial do Supremo. A de Zavascki foi confirmada. Quando será a de Gilmar? O que poderia fazer o presidente da corte, o ministro Ricardo Lewandowski? Nada. Cada ministro dispõe de um conjunto de prerrogativas que lhe permite fazer todo o Supremo pender ora para o holofote, ora para a sombra. [...] Em setembro de 2014 o ministro Luiz Fux decidiu sozinho que os 16 mil juízes brasileiros devem receber $\mathrm{R} \$ 4.377$ reais mensais de auxílio-moradia. Nunca levou sua liminar para avaliação dos
} Revista de Direito Brasileira | São Paulo, SP | v. 18 | n. 7 | p. 114 - 133 |Set./Dez. 2017 
A democracia, construída como um conjunto de formas e ritos, pesos e contrapesos, violentados pela imprevisibilidade, eis que poderia, conforme Tarso Genro ${ }^{17}$, descambar para 0 totalitarismo, onde a indeterminação e imprevisibilidade constrangem o espaço democrático possível. Por isso, em nome da segurança democrática devemos refrear a radicalidade de qualquer impulso utópico, em especial do próprio Poder Judiciário, já que este só pode fundar-se numa subjetividade e decisionismo que serão puras "aventuras" do espírito.

E por isso mesmo, eis que as palavras de Gisele Cittadino ${ }^{18}$ se encaixam muito bem neste contexto, pois a ampliação do controle normativo do Poder Judiciário no âmbito das democracias contemporâneas é tema central que hoje se processam na ciência política, na sociologia jurídica e na filosofia do direito. O protagonismo dos tribunais constitucionais e cortes supremas não apenas transformam em questões problemáticas os princípios da separação dos poderes e da neutralidade política do Poder Judiciário, como inaugura um tipo inédito de espaço público, desvinculado das clássicas instituições político-representativas. Ainda, a autora diz que confundir a política com o direito é certamente um risco para qualquer sociedade democrática e que é necessário uma responsabilidade democrática dos juízes quando se debate o tema da judicialização da política, pelo que a força do direito apoia-se na ideia da autonomia e dos direitos dos indivíduos.

No entanto, nisso tudo, fica o risco, por conta de uma rendição do Judiciário à tecnologia do sucesso, com a transformação do direito em simples e corriqueiro objetivo de consumo e, também, ao sabor das paixões consumistas que, na maioria das vezes, prima pela crueldade e exploração do medo. Nesta linha, Tercio Sampaio Ferraz Júnior já preconizava que a politização do Judiciário, neste sentido, é diferente da politização do Legislativo ou do Executivo, pelo que:

Diante de um Judiciário neutralizado, aqueles dois poderes produzem normas, mas não criam o direito. O poder político valoriza e desvaloriza direitos, ao lhes alterar a força de obrigatoriedade. Pode até usar e abusar deles. Os produtos normativos oferecidos pela atividade política do Legislativo e do Executivo não passam, porém, de mercadorias: têm valor de uso e valor de troca, mas não têm valia, isto é, não possuem valor em si. A neutralização política do Judiciário é que institucionaliza a prudência como uma espécie de guardião ético dos objetivos jurídicos. Ora, com a politização da justiça, tudo passa a ser regido por relação de meio e fim. $\mathrm{O}$ direito não perde sua condição de bem público, mas perde o seu sentido de prudência, pois sua legitimidade deixa de repousar na concórdia potencial dos homens, para fundar-se em uma espécie de coerção: a coerção da eficácia funcional. Ou seja, politizada, a experiência jurisdicional torna-se presa de um jogo de estímulos e respostas que exige mais cálculo do que sabedoria ${ }^{19}$.

Como bem ressalta Fábio Konder Comparato $^{20}$, o corpo de magistrados, entre nós, sempre integrou de modo geral os quadros dos grupos sociais dominantes, partilhando

colegas. Até agora, Fux custou R\$1,25 bilhões aos cofres públicos. Nenhum deputado ou senador é capaz de impactar o orçamento unilateralmente nessa magnitude. Disponível para acesso no site eletrônico: http://www1.folha.uol.com.br/ilustrissima/2016/04/1756464-com-regras-discutiveis-supremo-tribunal-federal-ganhaprojecao.shtml. Acesso em: 04 de abril de 2016, às 14h10m.

${ }_{17}$ GENRO, Tarso. Crise da democracia: direito, democracia direta e neoliberalismo na ordem global. Petrópolis, RJ: Vozes, 2002, p. 15.

${ }^{18}$ CITTADINO, Gisele. Judicialização da política, constitucionalismo democrático e separação dos poderes. In: VIANNA, Luiz Werneck (Org.). A democracia e os três poderes no Brasil. Belo Horizonte: Editora UFMG, Rio de Janeiro: IUPERJ/FAPERJ, 2002, p. 17.

${ }^{19}$ FERRAZ JÚNIOR, Tercio Sampaio. Direito constitucional: liberdade de fumar, privacidade, estado, direitos humanos e outros temas. Barueri, SP: Manole, 2007, p. 409.

20 COMPARATO, Fábio Konder. O Poder Judiciário no Brasil. In: ALMEIDA NETO, Manoel Carlos de; CAGGIANO, Monica Herman; LEMBO, Claudio (Coord). Juiz constitucional: estado e poder no século XXI: Revista de Direito Brasileira | São Paulo, SP | v. 18 | n. 7 | p. 114 - 133 | Set./Dez. 2017 
integralmente sua mentalidade, vale dizer, suas preferências valorativas, crenças e preconceitos, o que contribuiu decisivamente para consolidar a duplicidade funcional de nossos ordenamentos jurídicos nessa matéria. Ou seja, nossos juízes sempre interpretaram o direito oficial à luz dos interesses dos potentados privados, mancomunados com os agentes estatais, sem qualquer pudor, como um Poder único e autoritário que interpreta a lei sem qualquer adequação da resposta para com a Constituição.

\section{POR UM CONSTITUCIONALISMO DEMOCRÁTICO E HUMANISTA: A DEMOCRACIA ATRAVÉS DOS DIREITOS E DA HARMONIA DOS PODERES CONSTITUÍDOS}

A Constituição brasileira de 1988, elaborada logo após o encerramento do período ditatorial, quando ainda estavam muito vivas as marcas das violências praticadas pela ditadura, foi a expressão dos anseios de liberdade e democracia de todo o povo, em um Estado de Justiça Social e não apenas em um Estado de Direito. Ela foi também, e continua sendo, o instrumento de legítimo de consagração, com força jurídica, das aspirações por justiça social e proteção da dignidade humana de grande parte da população brasileira, vítima tradicional de uma ordem injusta que a condenava à exclusão e à marginalidade.

Segundo Dalmo de Abreu Dallari ${ }^{21}$, os antigos oligarcas, os aproveitadores da superioridade econômica, os viciados em privilégios de qualquer espécie, os resistentes à democratização da sociedade, de modo geral, percebendo o alcance político e social da Constituição, eis que têm feito duras críticas radicais à Constituição, sobretudo pelo que consideram presença excessiva do Estado na proteção e promoção dos direitos sociais, o que, obviamente, exige recursos financeiros. E isso, por sua vez, implica a cobrança de (mais) tributos, sendo este um dos principais motivos da resistência das camadas mais ricas da população. Referidas camadas considera, ainda, mais grave ainda o papel do Estado como controlador dos excessos da iniciativa privada na área econômica, pois no seu entender o Estado deveria ter apenas o papel mínimo do Estado, como simples guardião da liberdade econômica dos ricos, como fazia no início do século dezenove, Estado este que justamente por isso foi chamado de Estado Mínimo ou Liberal. Entendem, ainda, que o Estado deveria ser mero garantidor da liberdade econômica, geralmente identificada como liberdade de iniciativa, agindo, por isso, como um rigoroso repressor de quem atentasse contra essa liberdade, exercendo o papel de Estado Polícia, que foi também uma das expressões correntes nas primeiras décadas do século dezenove.

Ocorre, porém que a compreensão do Estado Democrático (Social) de Direito perpassa obrigatoriamente por dois princípios essenciais: o da dignidade humana (e o da justiça social). A interpretação de todo e qualquer direito deve ser feita à luz do princípio da dignidade da pessoa humana, pois o princípio indicará um mínimo irredutível dos direitos, consubstanciado no chamado piso vital; ainda, porque tais direitos tomam o homem como um valor não relativo, que, deste modo, não pode ter sua experiência digna sacrificada frente a interesses secundários da administração pública.

Assim, a democracia está intimamente relacionada com no mínimo três elementos, a saber: a proteção da dignidade, da liberdade e da igualdade. É, ainda, como bem afirma José Afonso da Silva ${ }^{22}$, que a democracia é a cooperação entre indivíduo e sociedade, entre

homenagem ao ministro Enrique Ricardo Lewandowski. São Paulo: Editora Revista dos Tribunais, 2015, p. 151 e 152.

${ }^{21}$ DALLARI, Dalmo de Abreu. Constituição e constituinte. 4. ed. São Paulo: Saraiva, 2010, p. 119.

${ }^{22}$ SILVA, José Afonso da. Liberdade, realidade política e eficácia da Constituição. In: MEYER-PFLUG, Samantha Ribeiro; ROCHA, Maria Elizabeth Guimarães Teixeira (Coord.). Lições de direito constitucional: em homenagem ao professor Jorge Miranda. Rio de Janeiro: Forense, 2008, p. 140 e seguintes.

Revista de Direito Brasileira | São Paulo, SP | v. 18 | n. 7 | p. 114 - 133 |Set./Dez. 2017 
governantes e governados para garantir as possibilidades de felicidade de cada um, numa idealização utópica que seria a identificação do governo e governada, que começa a realizar-se com a efetiva participação indireta e direta do povo no processo de poder.

Mas a democracia não pode ser mais ser concebida como essencialmente política, pois não poderia haver liberdade e igualdade política sem independência e igualdade de oportunidades econômicas e sociais. A verdadeira democracia se realiza no equilíbrio de todos os fatores necessários para darem o ser humano a maior possibilidade de expansão de sua personalidade. A democracia não pode aceitar um sistema econômico e social de profundas desigualdades, ela se realiza no dia-a-dia, acolhendo as forças que combatem por uma sociedade mais justa, mediante o reconhecimento de direitos sociais. Não tem mais cabimento o dilema de se a Constituição é uma técnica do poder ou uma técnica da liberdade, pois sua missão consiste em assegurar o respeito aos direitos fundamentais, e, quando ela institucionaliza o Poder, ela o faz como um meio de orientar o exercício do Poder para a proteção dos direitos sociais. Com o constitucionalismo, o Poder foi domesticado a serviço dos direitos da pessoa humana através da Constituição, mas a Constituição de 1988 não concluiu a reforma do Estado e deixou intacta a estrutura arcaica de poder, por meio da qual as elites conservadoras realizam a contrarreforma.

A luta pela Constituição há de desenvolver-se em duas frentes: a) na sua defesa contra as forças do retrocesso que não se conformam com conteúdo ideológico de transformações sociais nela incorporado e tentam por todas as formas recuperar o que perderam no processo constituinte, por meio de um processo de mudanças constitucionais; b) na participação ativa do processo político para refazer a realidade política que tem sido um fator que tolhe a sua eficácia social.

A Constituição oferece as bases, os pressupostos e os instrumentos de modernização; a prática política é que tem que coordenar os meios oferecidos para a consecução dos fins apontados na obra do constituinte. Como dito alhures, existe uma dificuldade contra majoritária no reconhecimento de que, diante da vagueza e abertura de boa parte das normas constitucionais, bem como da possibilidade de que eles entrem em colisões, quem as interpreta e aplica também participa do seu processo de criação. Daí a crítica de que a jurisdição constitucional acaba por conferir aos juízes uma espécie de "poder constituinte permanente" ou até mesmo como legislador positivo, pois lhes permite moldar a Constituição de acordo com as suas preferências políticas e valorativas, em detrimento daquelas adotas pelo legislador eleito. Essa visão levou inúmeras correntes de pensamento ao longo da história a rejeitarem a jurisdição constitucional, ou pelo menos o ativismo judicial no seu exercício.

Neste ponto, há profunda tensão potencial entre a jurisdição (constitucional) e a democracia. Se a imposição de limites para a decisão das maiorias pode ser justificada em nome da democracia, o exagero revela-se antidemocrático, por cercear em demasia a possibilidade de o povo se autogovernar. O problema se agrava quando a jurisdição constitucional passa a ser concebida como o fórum central para o equacionamento dos conflitos políticos, sociais e morais mais relevantes da sociedade, ou como a detentora do poder de ditar a "última palavra" sobre o sentido da Constituição. Em outras palavras, a dificuldade democrática pode não vir do remédio o controle judicial de constitucionalidade -, mas da sua dosagem. Para Cláudio Pereira de Souza Neto e Daniel Sarmento ${ }^{23}$, eis que não existe uma fórmula universal, válida para todos os países e contextos. Ela depende de fatores contingentes, como grau de representatividade dos poderes políticos majoritários, sua performance na proteção dos direitos fundamentais e de minorias, a credibilidade e independência do sistema judicial, e a existência, no âmbito do Poder Judiciário, de uma cultura não elitista, aberta aos anseios dos grupos e camadas mais vulneráveis da população.

${ }^{23}$ SARMENTO, Daniel; SOUZA NETO, Cláudio Pereira de. Controle de constitucionalidade e democracia: algumas teorias e parâmetros de ativismo. In: SARMENTO, Daniel (Coord.). Jurisdição constitucional e política. Rio de Janeiro: Forense, 2015, p. 84. 
Não é democrático assumir uma posição paternalista, diante de uma sociedade infantilizada. E, se não é correto, no debate sob a legitimidade da jurisdição constitucional, idealizar o Legislativo como encarnação da vontade geral do povo, tampouco se deve cometer o mesmo erro em relação ao Judiciário, supondo que os juízes constitucionais sejam sempre agentes virtuosos e sábios, imunes ao erro, sem agenda política própria e preocupada apenas com a proteção dos direitos fundamentais, dos valores republicanos e dos pressupostos da democracia.

Sem entrar no mérito, pelo pouco espaço, sobre a existência das diversas concepções sobre o papel adequado do controle de constitucionalidade em um regime democrático, tudo indica que antes, para se começar a acreditar e legitimar referido controle de constitucionalidade e no próprio Poder Judiciário, eis a necessidade de evoluir (o próprio Poder Judiciário) como um poder democrático em si e perante os demais, com no mínimo a procedência das reformas necessárias na própria organização, a saber: a) ampliar e aprofundar os instrumentos de controle do Poder Judiciário; b) instituir instrumentos de controle vertical, interno e externo, dos órgãos judiciários; e c) mudança na cúpula do sistema judiciário.

Montesquieu, na obra "O Espírito das Leis", Livro XI, capítulo 6, citado por Fábio Konder Comparato ${ }^{24}$, ensina que se faz necessário um aclaramento entre o poder estatuinte e o poder impediente no Poder Judiciário, tal como em Roma, por exemplo, em que os tribunos da plebe não tinham poder algum de criar leis ou ordenar a prática de atos jurídicos; mas a tribunicia potestas (sempre temida pelo patriciado) compreendia, entre outras competências, a de vetar qualquer ato de titular de cargo público, contrários aos interesses da plebe. Com base nessa distinção conceitual, percebe-se, desde logo, que ao Judiciário não competia nenhum poder estatuinte de criar normas gerais ou organizar serviços públicos. Mas ele possui no mais alto grau o poder impediente de corrigir e reparar, não apenas os desmandos dos demais órgãos públicos (e também dos particulares dotados de poder na sociedade), mas também em tese o de suprir as omissões constitucionais dos órgãos estatais no exercício de suas funções. E, para que isto suceda plenamente, é indispensável o estabelecimento de um sistema efetivo de controle dos órgãos judiciários, pois como Montesquieu ensinou na mesma obra citada acima que é uma experiência eterna que todo homem que dispõe de poder é levado a dele abusar; ele vai até onde encontra limites.

Importante assinalar que Montesquieu, na verdade, via na divisão dos poderes muito mais um preceito de arte política do que um princípio jurídico. Ou seja, não se tratava de um princípio para a organização do sistema estatal e de distribuição de competências, mas um meio de se evitar o despotismo real. Neste sentido, o princípio não era de separação de poderes, mas de inibição de um pelo outro de forma recíproca.

No entender de Bobbio, tanto "Direito" como "Poder", na sua origem, não podem ser distintos (lex et potestas convertuntur) e, mesmo depois, ainda andam de mãos dadas. Essa formulação do "Poder" é diferente da formulação positivista, que somente entendia o Direito como norma. Ainda, Bobbio afirma que:

Se olharmos pelo ponto de vista do Direito, como fez Kelsen com sua teoria normativa, no vértice encontramos - e não poderíamos deixar de encontrar - a norma das normas, ou seja, a norma fundamental; se olharmos pelo ponto de vista do poder, no vértice encontramos - como encontrou a teoria política do Estado moderno - o poder dos poderes, ou seja, o poder fundamental e soberano. Assim como a norma fundamental é a norma que está na base de todas as outras normas e acima da qual não há outra norma, também o poder soberano

${ }^{24}$ COMPARATO, Fábio Konder. O Poder Judiciário no Brasil. In: ALMEIDA NETO, Manoel Carlos de; CAGGIANO, Monica Herman; LEMBO, Claudio (Coord.). Juiz constitucional: estado e poder no século XXI: homenagem ao ministro Enrique Ricardo Lewandowski. São Paulo: Editora Revista dos Tribunais, 2015, p. 167.

Revista de Direito Brasileira | São Paulo, SP | v. 18 | n. 7 | p. 114 - 133 |Set./Dez. 2017 
é o poder que está na base de todos os outros poderes e acima do qual não existe outro poder superior ${ }^{25}$.

Porém, para ocorrer essa domesticação do Poder pelo Direito, se faz necessário um tipo específico de Estado, que é o Estado Democrático de Direito. Somente nesse tipo de Estado há uma situação de equilíbrio e de limitações entre o Poder e o Direito, para que se chegue a uma sociedade bem organizada. Esse equilíbrio é descrito por Bobbio, em que nos lugares onde o Direito é impotente, a sociedade corre o risco de precipitar-se na anarquia; onde o poder não é controlado, corre o risco oposto, do despotismo. O modelo ideal do encontro entre Direito e poder é o Estado democrático de Direito, isto é, o Estado no qual, através de leis fundamentais, não há poder do mais alto ao mais baixo, que não esteja submetido a normas, não seja regulado pelo Direito, e no qual ao mesmo tempo, a legitimidade do sistema de normas como um todo derive em última instância do consenso ativo dos cidadãos ${ }^{26}$.

Assim, assiste razão Luigi Ferrajoli ${ }^{27}$ ao ensinar que são múltiplas as razões de crise: a falta de introdução, sobretudo no âmbito supra e internacional, das garantias, sejam primárias ou secundárias, dos direitos estabelecidos nas várias cartas e convenções, como também de funções e instituições de garantia estatal.

De qualquer forma, nunca é demais insistir no tema da responsabilidade democrática dos juízes quando se debate o tema da judicialização da política. Se, por um lado, parece não restar nenhuma dúvida sobre a importância da atuação do Poder Judiciário no que diz respeito à garantia da concretização dos direitos da cidadania, é fundamental que o seu atual protagonismo seja compatível com as bases do constitucionalismo democrático.

Portanto, é temeroso que o processo de judicialização da política atue contrariamente ao império da lei e seus fundamentos democráticos, especialmente quando se espera que os juízes das cortes supremas atuem como profetas, deuses do direito ou Hércules - para utilizar a designação estabelecida por Ronaldo Dworkin ${ }^{28}$. É tempo de ser cauteloso e vislumbrar o caminho seguro de retorno ao Estado Democrático de Direito no país, no âmbito do constitucionalismo democrático brasileiro que se pretende resgatar a força do direito, rompendo com a tradicional cultura jurídica da força através do Direito.

\section{CONCLUSÃO}

Na democracia, o constitucionalismo substancialista e o devido processo legal são garantias fundamentais para estabelecer os meios idôneos e adequados para uma participação efetiva dos jurisdicionados na própria administração da justiça, a qual não é exclusiva nem "para", nem "do" e nem "com" o Poder Judiciário. Até porque não existem lentes adequadas para avaliar o Poder Judiciário em si, em especial o que acontece nos corredores dos tribunais ou nos "bastidores dos gabinetes".

É necessário que os poderes se limitem entre si, para evitar que se acumulem e se concentrem sem qualquer limitação. E isto é possível somente com base na velha receita de separação de Montesquieu, aplicada, porém a todos os poderes, velhos e novos, como meta

\footnotetext{
${ }^{25}$ BOBBIO, Norberto. O tempo da memória: de senectute e outros escritos autobiográficos. Tradução de Daniela Versiani. Rio de Janeiro: Campus, 1997, p. 104.

${ }^{26}$ Ibid., p. 170.

${ }^{27}$ FERRAJOLI, Luigi. A democracia através dos direitos: o constitucionalismo garantista como modelo teórico e como projeto político. Tradução de Alexander Araújo de Souza e outros. São Paulo: Editora Revista dos Tribunais, 2015, p. 147.

${ }^{28}$ DWORKIN, Ronald. Freedom's Law: the moral reading of the American Constitution. Cambridge: Harvard University Press, 1996. Na tradução para o português: DWORKIN, Ronald. O direito da liberdade: a leitura moral da Constituição norte-americana. Trad. de Marcelo Brandão Cipolla. São Paulo: Martins Fontes, 2006.
} 
garantia da efetividade de todos os direitos e dos limites e dos vínculos nos quais consiste a garantia de tais direitos.

A ampliação do raio de ação do Poder Judiciário não pode, no entanto, representar qualquer incompatibilidade com um regime político democrático, ainda que a incidência política da justiça possa variar segundo os países. O Poder Judiciário não deve agir como profetas ou deuses do direito, pois quando a justiça a ascende (ela) própria à condição de mais alta instância moral da sociedade passa a escapar de qualquer mecanismo de controle social. Evidencia-se que a força dirigente constitucional repercute desde o planejamento até a execução e o controle e avaliação das políticas públicas pela constitucionalização e jurisdicionalização da política e, mais ainda, pelas cláusulas de programaticidade constitucional que importam em promessas e compromissos de construção de um futuro melhor.

O Poder Judiciário em geral deve sensibilizar-se para combater sua própria vaidade, pelo que a população tem direito a ser protegida pelo Poder Judiciário de maneira que tenham ao seu alcance informações e tratamentos objetivos e científicos, não deformados por sensacionalismo, sentimentalismo ou argumentações moralistas.

Dentro de um Estado Democrático de Direito, cabe ao Estado concretizar mediante políticas à democracia social e econômica que visem a prevenção de uma crise institucional entre os próprios Poderes constituídos, ainda mais em Estados de capitalismo periférico com alto grau de exclusão social e com renovadas manifestações de questão social. Em um Estado Democrático de Direito, o Poder Judiciário deve entender a si mesmo como protetor de um processo legislativo democrático, isto é, como protetor de um processo de criação democrática do direito, e não como guardiã de uma suposta ordem supra positiva de valores substanciais. A função do Poder Judiciário é velar para que se respeitem os procedimentos democráticos para uma formação da opinião e da vontade política de tipo inclusivo, ou seja, em que todos possam intervir, sem assumir (ele mesmo) o papel de legislador político.

Conclui-se, assim, que se hoje nos permitimos discutir o papel do Poder Judiciário diante da harmonia entre os poderes, é porque fomos capazes de superar o autoritarismo e reconstruir o Estado Democrático de Direito, promulgando uma Constituição que, nesse processo, representa um consenso em torno de princípios jurídicos universais. Portanto, a Constituição brasileira não pode ser tomada como uma ordem particular de valores e o processo de judicialização da política não deve exclusivamente invocar o domínio dos tribunais, em uma juristocracia ou supremocracia, nem defender uma ação individualista por parte do Poder Judiciário.

\section{REFERÊNCIAS BIBLIOGRÁFICAS}

ALMEIDA NETO, Manoel Carlos de; CAGGIANO, Monica Herman; LEMBO, Claudio (Coord.). Juiz constitucional: estado e poder no século XXI: homenagem ao ministro Enrique Ricardo Lewandowski. São Paulo: Editora Revista dos Tribunais, 2015.

BOBBIO, Norberto. O futuro da democracia - Uma defesa das regras do jogo. $4^{\mathrm{a}}$ ed. Rio de Janeiro: Paz e Terra.

O tempo da memória: de senectute e outros escritos autobiográficos. Tradução de Daniela Versiani. Rio de Janeiro: Campus, 1997.

CANOTILHO, J. J. Gomes. Direito constitucional e teoria da constituição. $7^{\mathrm{a}}$ ed., $9^{\mathrm{o}}$ reimpressão. Coimbra: Almedina, 2012. 
CITTADINO, Gisele. Poder Judiciário, ativismo judiciário e democracia. Disponível em: http://revistaalceu.com.puc-rio.br/media/alceu_n9_cittadino.pdf.

CUNHA, Paulo Ferreira da. Direito constitucional e fundamentos do direito - Diálogos interdisciplinares. Rio de Janeiro: Renovar, 2008.

DALLARI, Dalmo de Abreu. Constituição e constituinte. 4. ed. São Paulo: Saraiva, 2010.

DWORKIN, Ronald. $O$ direito da liberdade: a leitura moral da Constituição norte-americana. Tradução de Marcelo Brandão Cipolla. São Paulo: Martins Fontes, 2006.

FERRAZ JÚNIOR, Tercio Sampaio. Direito constitucional: liberdade de fumar, privacidade, estado, direitos humanos e outros temas. Barueri, SP: Manole, 2007.

FERRAJOLI, Luigi. A democracia através dos direitos: o constitucionalismo garantista como modelo teórico e como projeto político. Tradução de Alexander Araújo de Souza e outros. São Paulo: Editora Revista dos Tribunais, 2015.

GARRIDO, Alexandre (et. al.). A função legislativa do Supremo Tribunal Federal e os Partidos Políticos. Revista Jurídica da Faculdade Nacional de Direito da UFRJ. V. 1, n. 3 (Edição Especial), dez. 2008, Rio de Janeiro, Faculdade Nacional de Direito, 2008.

GENRO, Tarso. Crise da democracia: direito, democracia direta e neoliberalismo na ordem global. Petrópolis, RJ: Vozes, 2002.

GUERRA FILHO, Willis Santiago. Teoria processual da constituição. São Paulo: Celso Bastos Editor - Instituto Brasileiro de Direito Constitucional, 2000.

HARTMANN, Ivar. Com regras discutíveis, Supremo Tribunal Federal ganha projeção. Disponível em: http://www1.folha.uol.com.br/ilustrissima/2016/04/1756464-com-regrasdiscutiveis-supremo-tribunal-federal-ganha-projecao.shtml.

MARINONI, Luiz Guilherme; ARENHART, Sérgio Cruz, MITIDIERO, Daniel. Curso de Processo Civil. Tutela dos direitos mediante procedimentos diferenciados. $2^{\mathrm{a}}$ edição. São Paulo: Revista dos Tribunais, 2016.

MEYER-PFLUG, Samantha Ribeiro; ROCHA, Maria Elizabeth Guimarães Teixeira (Coord.). Lições de direito constitucional: em homenagem ao professor Jorge Miranda. Rio de Janeiro: Forense, 2008.

MIRANDA, Pontes de. Tratado da ação rescisória, das sentenças e de outras decisões. 5. ed. Rio de Janeiro: Forense, 1976.

MOREIRA, José Carlos Barbosa. Temas de direito processual: oitava série. São Paulo: Saraiva, 2004. 
OLIVEIRA, Flávio Luís de. Tutela jurisdicional e concretização de direitos. In: Revista do Direito Privado (Londrina, Estado do Paraná), v. 03, p. 01-12, 2010. Disponível em: http://www.uel.br/revistas/direitoprivado/artigos/Flavio_Luis_Oliveira_Tutela_jurisdicional_con cretiza\%C3\%A7\%C3\%A3o_direitos.pdf.

PARIZ, Ângelo Aurélio Gonçalves. O princípio do devido processo legal: direito fundamental do cidadão. Coimbra: Almedina, 2009.

SADEK, Maria Tereza (Org.). O Judiciário em debate. São Paulo: Idesp/Sumaré, 1995.

SARLET, Ingo Wolfgang. A eficácia dos direitos fundamentais: uma teoria geral dos direitos fundamentais na perspectiva constitucional. $11^{\mathrm{a}}$ ed. Porto Alegre: Editora Livraria do Advogado, 2012.

; MARINONI, Luiz Guilherme; MITIDIERO, Daniel. Curso de direito constitucional. 4. ed. São Paulo: Saraiva, 2015.

SARMENTO, Daniel (Coord.). Jurisdição constitucional e política. Rio de Janeiro: Forense, 2015.

TELLES JÚNIOR, Goffredo. A Constituição, a Assembleia Constituinte e o Congresso Nacional. São Paulo: Saraiva, 1986.

VIANNA, Luiz Werneck (Org.). A democracia e os três poderes no Brasil. Belo Horizonte: Editora UFMG, Rio de Janeiro: IUPERJ/FAPERJ, 2002.

VIEIRA, O. V. Supremocracia: vícios e virtudes republicanas. Valor Econômico. 06 de novembro de 2007. 